\title{
Telenovela, an Instrument for Democracy
}

\author{
Sina Eskandari ${ }^{1}$ \\ ${ }^{1}$ Department of Human and Social Sciences, University of Almeria, Almeria, Spain \\ Correspondence: Sina Eskandari, Department of Human and Social Sciences, University of Almeria, Almeria, \\ Spain. E-mail: sinaeskandari@ut.ac.ir
}

Received: May 17, 2017

doi:10.5539/res.v9n3p106
Accepted: May 23, 2017

Online Published: July 16, 2017

URL: http://doi.org/10.5539/res.v9n3p106

\begin{abstract}
Telenovela shapes important and highly favorite section of the television productions. The T.V. series have moved out from their traditional structure with an entertaining aspect and have been divided into different types and scopes. Taking into consideration the time and the atmosphere of dissemination which the Telenovela programs hold in T.V. antenna, there is a need to conduct studies on sociology of Telenovela more than any other times in the past. This article is an attempt to review the two subject-matters of Telenovela and Narration and their connection with democracy through sociological sporadic studies. This will also present the significance of this genre in T.V. productions at local and international discourses. Observations, field researches and library study methods have been employed in this research.
\end{abstract}

Keywords: Telenovela, television, democracy, peace, education

\section{Introduction}

Television series and basically any audio visual phenomenon will not find meaning without a narration. Roland Barthes believes that culture in a larger scale is comprised of various narrations. Myth, fable, tale, story, epic, drama, folk tale, satire, pantomime, painting, film, news, dialogue and even partial description of each subject are parts of our daily experiences of narration (Ohadi, 2012). Narration has existed since the beginning of human history and has always been prevailing among all cultures and nations. Thus, we should take into consideration the narration as the base of whatever we see in T.V. screen. A prerequisite to reach democracy is the creation of civilization. Each civilization is a scheme and each democracy is in need of an informed society. This plot or scheme is not met today by military strategies and giant warfare. The world has changed and we rarely see people in boots as the advocator of freedom and democracy. The recent Turkish failed coup d'état attempt in July 2016 confirms this idea. Technology could overcome the boot and the T.V. message of coup d'état attempt perpetrators was responded with the message of the President of Turkey. Hence the Government could prevent from undemocratic methods to make political changes (Berk Esen, 2017).

In another example, Egypt made a revolution by internet campaign, though it was not successful to protect the revolution but the very movement towards democracy was started through social networks and the last word of the Egyptian president was displayed in Tahrir square through T.V. (Philip \& Howard, 2011).

Perhaps, the narrations of the book of the Republica by Plato could be considered as the first narrative democracy letter. Later on, Francis Bacon writes the narration of Utopia with the book of New Atlantis (McKnight, 2007). In order to grasp the link between narration and democracy, we refer to Shahnameh [Epic of kings] by Ferdowsi [Iranian classic poet]. Shahnameh holds sequenced poems by Ferdowsi. The Persian Shahnameh was versified when Arabs had dominated Iran after attacking on Persian people. The formal religion had been changed and the Persian language was banned. Thus, 1200 years ago, versifying Shahnameh, Ferdowsi revived the spirit of epic, freedom and bravery within the framework of narrative poems to enable the Iranian to have a government independent from Arabs. The role of Fredowsi and his narrative poems in very noticeable in returning Iranian to the Persian identity and their present distinction from the Middle East countries which had been invaded by the Arabs (Shobeyri, 2013).

Narration can be a way to achieve democracy or a factor to violate it. In the colonization age, the superpowers used to re-narrate certain narrations within the framework of tales to make their performance to be justified in the reader's imagination. The control of public opinion and trampling the principles of democracy was being made with the publication of tale and novel ranging from Robinson Crusoe and Gulliver's Travels to today's 
films of Argo, 300 and American Sniper. If 298 years ago, the Robinson Crusoe novel narrates a white British who reaches an island and challenge with a wild African, today in the gray screen, Captain Philips should deal with fighting against the Somalia black wild people in the Indian Ocean (Greengrass, 2013).

Thus, it can be concluded that narration has not been changed but there has been a change in the narrative instruments. In both models of film and fiction literature, the objective is to justify the military presence of Britain and USA in the oceans of other countries for the purpose of civilizing the wild population and then achieving the democracy (Abbasi, 2015).

Colonization-oriented narration in the T.V. frame imposed the strongest type of violation of democracy on the target society. Colonization and trampling the identity of nations in film and series were being performed in two forms. For example, in the model of British colonization, whatever used to inspire to the viewer were as follows:

1) If an Indian was helping the British and betraying his countryman, a satire and humor was taking shape.

2) If an Indian was helping his countryman, and saying No to the British, then a betray and wildness was taking form.

Watching T.V. has more attitudinal impact rather than behavioral one. On this case, two topics of the main current and resonance in the cultivation theory is put forth. Cultivation refers to the accumulative and integrated process by which T.V. breeds beliefs about the social realities. That is a reference to the impact of T.V. in stabilization and unification of viewpoints inside the society. The high rate of watching T.V. has different results for different social groups. James W. Tankard believes that the main current building occurs when the over watch of T.V. leads to the conjunction of views in the society and in the topic of resonance, the impact of cultivation on a part of the society increases and at the same time, the addresses see the T.V. programs in agreement with their daily realities (Ghavam, 1996).

Considering the analytical model based on cultivation theory, the type of attitude, beliefs and even taking stands towards the surrounding issues, the type of political awareness and view towards incidents in particular cultural discourse (which are manifested in diverse genres of this network) gradually influence the addresses and the redisplayed culture will have impact on their political culture and attitude in long term. As for the control of public opinion by media, Chomsky puts forth the example of UK and the World War I and interference of anti-war public opinions with the political ideas of warmonger government, when political propaganda commission and Creel Committee, relying on the elites of the society changed the views of people about the war for 180 degrees within six month time. He considers the democratic liberal systems on media issue similar to ideologue systems [Creel Committee: The Committee on Public Information, also known as the CPI or the Creel Committee, was an independent agency of the government of the United States created to influence U.S. public opinion regarding American participation in World War I]. Both are pursuing to lead the mind and understanding of people and consider them like a flock that will lose the way if they do not have a shepherd (Chomsky, 1988).

\section{Method}

In this paper, the library studies, online sources and sources available in journals have been used to study Telenovela in different parts of the world. In addition, observing and processing audiovisual sources related to Telenovela of El Capo, certain references have been made to the course of the story trend and socio-political incidents of Colombia. Developing questionnaire, I had first-hand interviews and consultation with various walks of life from the targeted countries and could gain their feedback as one of the reliable true reelection towards these types of T.V. series productions.

\section{Results}

Understanding the important role of financial backup and ideologue of a long term T.V. set or the very Telenovela, the reading and performance of Telenovela in democratic and undemocratic societies will be dealt with:

Hugo Chavez came into power as a favorite officer in 1999 and up to 2003, Venezuela was experiencing a period of freedom after change. Chavez began to adopt new decisions which were detaching Venezuela from the seashore of peace and its consequences were terrifying the people. Chavez called the private media like the media of the enemy. The Costita Rica Telenovela which was produced with the subject-matter of referendum of Chavez, was encountered with the sharp reaction of Venezuela government. It was to the extent that hard rules were applied to exert pressure and restriction on T.V. products, a law under the title of Ley de Responsabilidad Social en Radio y Television (Ley Restore), the social responsibility in radio and television. 
According to this undemocratic law, the contents of social media were written and the individuals who do not respect to the law of control of medial or Resorte, certain restriction, ban and punishment are applied. This law strongly puts forth the importance of Telenovela in social and political interaction of Latin America. In a speech in January 2001, Hogue Chavez asks for the production of socialistic Telenovela and something different from capitalistic Telenovela, of the same Telenovela which are produced by the bigger revolutionary brother (Azorín, 2013).

The first Telenovela of Bolívar was Teresa en tres estaciones. The story of sisters which thanks to the Bolivarian revolution and its developmental facilities such as railway which was built by Chavez in 2006, could sell their products and their life had undergone changes thanks to the grace of revolution (Pardo, 2015).

Today definitely, no Telenovela reflects the social, economic and political crises in Venezuela. The slight genre of Telenovela being built are on love issues and the pressure groups and censorship emphasizes on the content control (Anne, 2015). The escape of the elites to the neighboring countries, defected economy and tension-stricken politics has made the T.V. industry and Telenovela production reach to the border of bankruptcy.

Experts of Turkish issues, after Erdogan came into power and became president and also the emergence of dispute inside the party, gave alarm about what happened in Venezuela [similarly] in the scope of media. Some experts believe that the target of Erdogan is to rebuild the Muslim emperorship of Othman within the shaky framework of the present secularism (Danforth, 2016).

In a speech, Erdogan attacks at The Magnificent Century Telenovela and cleans his ancestors from what has been introduced by Telenovela in 80 countries of the world (Zalewski, 2012). Anyway, it is a reality that it is not possible to ignore the role of Turkish Telenovela in the success of the cultural diplomacy of this country outside the borders (Zafer Yoruk, 2013).

In The Korean Telenovela is the international rivals of Turkish and Latin American Telenovela. The relation of the Korean with democracy is defined of another type. Telenovela has been converted into an instrument for reaching the democracy in the North Korea too. Watching South Korean Telenovela in the North Korea has the death penalty. The series of Doctor Stranger, is the story of a physician who takes a travel to North Korean to treat the former leader of the North Korea. The Korean authorities have legislated very strict punishments to avoid any kind of distortion of the history. The reports from the North Korea show that the series of the South Korea have specific favorite among the school and university students. The new generation overpasses the fabricated walls of dictatorship around themselves and identify a world in which all officials have tried to tell that world had nothing but ruin and misfortunate. According to the estimations, daily between 1000 to $3000 \mathrm{CD}$ and files are distributed among the students (Yong, 2014). As it was said earlier, the contents of the Korean Telenovela is the high welfare level of the middle class (the public), the cultural issues and the ideological gap between the generations and lovely relations. The simplest hypothesis about the line and target of the South Korean Telenovela industry is that the northern addresses in the first stance compare their conditions with the southern neighbor. Then they reconsider in their having and not having and this can be the beginning of idea of change for a better society in the North Korean (Mailonline, 2014).

The Chinese have also legislated strict rules about the role of media with a new attitude which makes the T.V. and cinema industries shake. According to this law, the films should not encourage gambling, superstitions, drug consumption, and violation or educate criminal methods. More importantly, they should spread values such as serving the people and socialism. In addition, according to the new law of censorship in China, the films which hurt the national emotions or cast doubt on national unity will have no permit for production. This paragraph of law can include all controversial incidents and personalities of the history of China (McDonell, 2016).

In the end, we believe that the Ideologue countries are at the top of visible censorship of media and in particular Telenovela. Producing series in the course of time will lead to lose of addressees due to the monopoly of media in these counties. Thus, satellite, internet and smugglers of cultural products play the main role in showing the foreign Telenovela. Having the lack of suitable knowledge, the target society faces disruption and not only are aware of the layer designed for reaching democracy (Like El Capo), but also fill their circles with superficial layers which are full of cultural banalities and experience unfavorable social consequences. The sample of these feedbacks in different spots of the world confirms our claim. For instance, Brazil and Turkey, both in connection with the social damages have not been secure against the censorship phenomenon. Earlier, the necessity of sociological study of expectation and patience was discussed. What has occurred in these countries as an unfavorable consequence is noticeable. When a male-oriented society pushes away the women into the house and asks women to follow the tradition and in the social atmosphere, a gender justice gap is put forth, in the 21 st 
century, the women are confined to a home and fill their expectation by watching a Telenovela which penetrates in their life during the course of the time.

It can be accepted that waiting for the return of husband and children from work and school has been filled in for watching Telenovela. Telenovela has possessed anticipation for itself and has imposed itself to the family. Telenovela has given name, face, spirit, body and adventure to expectation (waiting). Many causes of those who condemn Telenovela in the family court can be attributed to this consequence.

When a woman is waiting at home to wait for the good looking hero of the story at home and her husband does not have the conditions of beauty and good dress of the pre-marriage era after years of common life, the attractions have diminished and the tendency of women to other men (mostly in a lower age than themselves) who are similar to the personalities of Telenovela protagonist increases and irregular affairs take shape (Verón, 1997). Family courts in Muslim countries have become full of such cases and authorities blame the Telenovela for it. In the Iranian courts, a section has been allocated to the damaging impact of T.V. series and the related cases are referred to it. This section is so called "GEM" (the name of the network distributing Telenovela after 2009 election). The issues of patrimonial problems not only have entangled the Muslims but also other communities.

In Brazil, also unfavorable consequences have taken form despite high benefits in the positive role of women on pregnancy control, literacy and health of which one can point out the lack of trust of couples to each other, sexual adventure seeking and insulting to the family values (Alberto Chong, 2009).

George Orwell had forecasted that the history will be destroyed by totalitarian governments. A ministry would have been shaped under the name of the Ministry of Truth which undertakes to disappear the unfavorable activities by the governments and purge the documents related to the past (Chomsky, 1988).

Perhaps, it will be possible to attribute the emergence of Wiki Leaks to him (Fighting against ideological censorship). This is a model which is exactly taking place in the model of censorship in some countries. Each write their history as they like to imagine. The cultural policy makers play a basic role in producing the contents of Telenovela. In the view of Robert Dahl, the advanced political culture has some characteristics:

The first characteristic of the advanced political culture is that the people should have political awareness and be aware of their benefits. In Colombia, policy has made people to be disgusted of politics and a new will is going to take shape with recent measure adopted by the state, peace private organizations, guerrilla fighters, officials of Nobel Prize, president, Cuba and parliament.

The second characteristic is the creation of a participatory culture. That is to say that in order to be able to gain his rights in the political competitive world and could participate in determining his future fate, with what kind of mechanism can take part, an option which in the third chapter is ahead of the Colombian people.

The end of violation, polling box, ignoring the previous mistakes, coexistence, legalizing the drug and decriminalization of the controlled consumption of drugs in Colombia which in case of economic reforms and replacement of cocaine trade with another trade will succeed. The third characteristic which is considered a part of the non-development indicators of political culture is political self-confidence. That is to say that an individual could have impact in the political world and his fate and society does not have any relation to fate. An incident which is shown in El Capo Telenovela in another form, the opening of the black box of Colombian politics, imposes the social disappointment for micro participation on the viewer. Interpretation of participation in Colombia is perhaps armed struggle which Telenovela sends it towards peace like the option of creating a participatory culture. The fourth characteristic of the advanced political culture is trust in the government which seems to have no place in Colombia. The amendment of the economic-administrative structure is the most important request of people. A society in which there is a decrease in trust in government, from the viewpoint of political culture is a back-warded society. So, both social trust is important and political trust which both of them stands in the stage after political self-confidence. On this basis, the main indicators of an ideal and grown political culture should be known in positive direction of people towards the political system healthy relation between political elites and people in power and daily increase of positive feedback (Ghavam, 1996).

-New political culture-Democracy

-Accepting responsibility for change in the society conditions

-Political awareness through Telenovela

-Political trust in Telenovela solution

-Political participation for achieving Telenovela objective 


\section{-Watching Telenovela}

Telenovela is a strong instrument in the hands of the T.V. producers. Telenovela is an educational tool which can be at the service of democracy and at the same time, it can stands opposite to the democracy too. When Telenovela is broadcasted in a society different from the main receivers of the producing country, it causes a disruption in the cultural percepts and the learning from the set will be superficial and mostly associated with social abnormality or banality.

\section{Discussion}

The case study of this research is the Colombian Telenovela of El Capo, a Telenovela of the type of fight and pursuit story, a thriller story and an exciting tale. Jose R. Valles Calatrava believes that all mentioned genres can be placed easily as a sub-set of Criminal Story, criminal stories for the public or mass literature (Calatrava, 1990).

Telenovela was the first T.V. package of Latin America which could lead to income generation in the Europe, Asia and even USA (Nora Mazziottti, 1993). Basically, the cultural atmosphere of Latin America in recent years has been converted into a place for question and expression of belief about the concept of alterations which have been brought to them by modernization. Amid these, T.V. as a mediator between addressees and policy maker performs a strategic role in modernization process (Nora Mazziotti, 1993).

The El Capo Telenovela written by Gustavo Bolivar directed by Lilo Vilaplana and Riccardo Gabrielli has gone to air since 2009 through the antenna of Fox Tele-Colombia network and has been received warmly in various countries of the world. The hypothesis of the research is to pave the way of democracy by El Capo Telenovela. Whereas in the real world, the thieves, smugglers, and corrupted agents and government administrators are not exposed to judge and accountability before the justice. In Telenovela, the culprits are identified and trailed by the hand of fate or justice. In other words, they are judged and trailed in T.V. Moreover, efforts are made to reduce the tension and violation in the real world and T.V. screen justice-seeking attitude to serve as a healing to the real injustices of the world. Gustavo Forrero, an export of black novel believes that the countries of Mexico, Guatemala, El Salvador and Colombia move ahead their criminal stories with one literature. The pivot of all of them is drugs or smuggling and the corruption of sovereignty and weakness of rules in this genre are the main elements. Also, there is always punishment against the culprit whereas in the real world, it is far from reality that justice could deal with the large group of evil doers. As the social and political trust has been diminished with the expansion of mass media and divulge of the back of the scene, so that the classic model of crime, investigation, response and punishment in the style of black list is not convincing the addressee and an action and reaction model with an exciting rhythm makes the style of contemporary black novel (Forrero, 2015).

After passing three chapters from the broadcast of this series, beyond security, the Colombian liberal democracy is attacked by one of the biggest drug smugglers in Latin America. The loss of democracy increases crimes, instability and insecurity. It seems that the fear which is transferred to the viewer because of losing liberal democracy will lead to a social instrument for the control of the addresses in the long term. Today, the physical prisons are not suitable instruments for social control. Social control emerges in the public opinion. The fear of losing liberalism is propagated while in one side, there is Colombian problem of armed army of Farc with a communist structure and on the other side the criminal character of antagonist and protagonist which is being laid down based on populist Marxist ideas.

The Individuals who believe in justice of the type of distribution of wealth house by house rather a written economic structure and far from corruption. Recently, the Colombian government has signed a new peace deal with Left-wing rebel group the Farc recently. Thus, facing in two fronts of liberalism and new Marxism is always put forth in the underneath layers of the work. Basically, the emergence of black and criminal stories is in need of the advancement of industrial and liberal societies which in its own bed ground grow poverty, injustice and violation and the resulting criminal character of gaps and class injustices (Calatrava, 1990).

According to the observations of the past three chapters of El Capo series, it seems that the author intends to revive Pablo Escobar, the Colombian big smugglers within the stature of Pedro Pablo Leon Jaramillo to pass the cliché related to his life that had stopped the Colombian society in the years of the last decade of his life and change the political culture of Colombia and beyond that; the Latin America fundamentally. Writing another end to the life of El Capo, the author tries to change the tough life of Pablo Escobar slowly, so that with a more humane image, it could be accepted by the addresses and put an end to the cycle of violation in the society. In other words, the El Capo series tries to present another image of Pablo Escobar with the condition of living in present conditions, thus to push the viewers who have remained in 1980's to move ahead for their country. Based on the observations made, it is assumed that the ideal hypothesis of the writers of El Capo series has been 
directly laid down to end the defeated ideas of the leftist warrior and corruption of liberals. The Colombian modernization is not a cause for culturalization. It seems that it is the danger of prevalence of lumpenproletariat which has created such an idea in the mind of El Capo series. One of the objectives which are given to the Colombian addresses is the lack of seeking justice in personal form, such that they should leave the performance of justice to the authorities. Though everything is corrupted, there are small numbers of trustworthy and patriotic agents who are pursuing justice, but the result is not so much in agreement with this important ideal. Velandia, plays the personality of a good police but weak, a good police by faithful to the law in three chapters of El Capo. $\mathrm{He}$ is always seeking to revenge but at the moment of decision making, he acts as instructed by the law and does not prefer revenge to escaping from the law.

In criminal and black Telenovela, the omniscient orients the viewer towards watching the black box of politics of these countries, to the extent that the viewer comes into the surfaces from the complexities of the story and forget the main line of the story, i.e., striving to perform justice and reach to the famous phrase which reads' politics is dirty. Thus, the addresses only think on macro changes with public and electoral options to reach the justice. In a word, it is assumed that participation at micro level has no impact and response to the justice-seeking demands comes out only from the voting box.

Consequently, the influence of political ideas in criminal Telenovela such as El Capo, is aiming at educating the repulse of violation and pulling people into democracy seeking boxes. Showing the back of curtain, the El Capo Telenovela makes the society a politic-stricken society and creates a kind of social disappointment in the society. In a large scale, the solution of transit into an ideal society is defined as being far from violation and forgiving.

\section{The Study of the Social Impacts of Telenovela on Various Communities}

In this part, some samples of the impacts of Telenovela on political, social and cultural incidents of countries are presented.

\subsection{Brazil}

Perhaps Brazil could be identified as one of the pioneer countries in putting forth the political and social discussion on Telenovela, a country which according to Elodie Perreau has established the first school of Telenovela entitled "The Broadcasting of Telenovela". The Brazilian creative authors and youth in the years of military dictatorship (1964-1985) used to go to this school and were writing with a critical view in T.V. on micro-culture and entertainment subjects of Telenovela. Creating personalities and dramatizing the work and daily atmosphere and with regard to the lack of justice-seeking courts, the authors were creating discussion about the performance of personalities in the stories. Gradually, it was the public opinion who were judging them in the T.V. frame and the position of judge was being changed from up to down. It was not only the militants and their courts which were giving decree but people were also standing in the position of ruler and judge and this by itself was giving self-dignity to them and it was an exercise to achieve democracy. One of the other impacts of Telenovela in Brazil was its educational role in controlling the population. In 1970, the number of birth rate diminished and pregnancy showed a $60 \%$ of decrease. Also the statistic of divorce increased by five times. In other observations, for example, the Telenovela of Lazos de Familia which was broadcasted in 2000 was acknowledged for spreading the culture of organ donation (Azorín, 2013).

\subsection{Turkey}

Turkey has been mixed with social and political complexities of the region. The Turkish Telenovela have broken the simple formula which says whatever comes from the west is good. In the Muslim societies, the element of lack of secularism and religiosity of the series and the families which are narrated causes a safe shelter wall between the viewer and Telenovela (UNUR, 2015). In Turkish Telenovela, woman stands against the religious rules and traditional form of the family. The independency from the family, breaking the judgment of the society and its change play an important role in the main characters of the story. Woman in the Middle East is mainly shown with a dual, strong and vulnerable personality. In Turkish Telenovela, woman is a combination of modernity and traditionalism, a sensitive border in the culture of Middle East people. The pulse of the tales goes ups and downs in this very point, modernity, what is imagined in today's Europe and or traditional, a person who stays at home and her life is spent for the sake of family and she desires to escape from the traditional role which has been drawn for her by reactionary attitudes. There is no doubt that the personalities of woman in Turkish Telenovela are seeking to change the social norms. Omar al-Ghazi, an expert of cultural issues of Turkey believes that the Turkish Telenovela has modeled the enticing modernity. He further adds, "The idea of stories is very simple. A middle class family who is thinking on challenges such as migration from village into the city, progress and a better life, a case which is put forth from many individuals such as family values" (Tali, An unlikely story: Why do South Americans love Turkish TV?, 2016). 
The role of Turkish men is a transit from patriarchal culture into a civilized man of the modern world. The men, who do not beat, buy flowers, make surprises and reprimand violation against women. They get familiar with their partners mostly in the work environment or universities... There are many other cases which cannot be included in this article but in order to have a better understanding of the subject-matter, the first Turkish Telenovela which became famous outside the Turkey will be discussed, i.e., Love Prohibited and syndrome Mohanned. The protagonist of the story though has an irregular relations with the wife of his uncle but for many of the Muslims is a symbol of a gentleman and his model of behavior, a person who attaches significance to the character of woman, holds birthday party, and loves. The normalization of lovely life was one of the norms which shook the Muslim societies. Finally, the Muslim communities are facing generation gap. Saudi Arabia, Afghanistan and Iran have announced Telenovela as something unethical and unlawful poisoned product (Andra, 2012).

That they spend millions of dollars and hours to fight against Telenovela indicates the daily danger of life norms and models which are put forth by Telenovela in communities in a standard form and makes the society encounter with the danger of explosion for modernity and change. A question which is arisen here is that whether or not, how many societies can be affected by the T.V. series targeted arrow? In other words, is it possible to consider a Telenovela with the public phonology of construction and impacts without the geography of the target society? Concerning the impacts of broadcast of Turkish Telenovela in other countries, it is possible to refer to the Latin America. In Chile, the names of Onur and Sherezade are among the most favorite names for naming the infants. The mode of them of parties with the subject-matter of the Tales of One Thousand and One Night (the series of magnificent evening) is interesting in its type. The Chile people consider the high quality of production, touchable stories, avoiding Hollywood sex clichés, love stories and new subjects as the factors explaining the success of Turkish Telenovela (Chamy, 2014). In Iran and Latin America, the classes of Turkish language have been prevailed so much. Many administrators of Turkish sites are dealing with learning Turkish daily language and culture of Turkey to be able to translate the original version and upload them on their websites. This will help with the increase of viewers and some people goes to these classes only to watch the films in original language (Basar, 2015; Natalia Ferreira Barbosa, 2016).

\subsection{South Korea}

South Korea, the giant of producing Telenovela in the east in recent years has found a way beyond the borders of Korea through Telenovela and it T.V. products have been sold in more than 90 countries. The Korean Telenovela is mostly in lovely melodrama family or historical forms. In melodrama, families enjoy an ideal level of welfare. Respect to elders and traditions are seen. The technology is used frequently. There is security in economy and society and most of the subject-maters have an entertainment aspect. The tourism industry of South Korea and Korean language are the hidden elements in the underneath layers of the narration with aims to capture the T.V. antenna. Tourist exchange and learning the language is a part of the Korean non-governmental cultural diplomacy, but the study of the consequences of the broadcast of Korean Telenovela should firstly be sought among the neighbors. Among the neighbors, Vietnam and North Korea are the two countries which have been facing the outcomes of watching Telenovela. In Vietnam, a country in which the marriage agency have been banned recently, the number of women who marry with Korean men after watching the Korean Telenovela have increased. Out of the four hundreds of a statistical sample in a research, it was found out that 25 percent of them have learned about Korea about Telenovela. Among these women, those with les education were the greatest rate of Korean Telenovela addresses. Only 3\% of them had a higher education background. $40 \%$ had a guidance school education, $36 \%$ were graduates of secondary schools and $18 \%$ had left education after primary level. 3\% also had never had any educational background. It seems what has happened in Vietnam is related to the cultivation theory. That is to say, to the extent that people watch T.V., to the same extent, they believe that what is displayed by T.V. about society and their life is true and real, even if it is highly distorted. In fact, the cultivation is a common worldview which dictates the common values. This research shows that those with a better economic and academic levels have gone less under the influence of Telenovela and have referred to other sources to learn about Korea. Whereas many of women have become familiar with Korean through Telenovela, they gamble over the partner of their life in order to have a welfare level which is observed in the showing screen and in practice trust in what is shown by Korean Telenovela as a model ( $\mathrm{Vu}, 2013)$.

\subsection{India}

In India, where T.V. and cinema enjoy an ideal dynamism, also Telenovela has had different position and social impact and some invest in Telenovela production directly. As for media education topic, India has a record in it. In Indian Telenovela, usually topics such as adult literacy, family control, situation of women (recently combating the violation against women and rape) and health are included. After the successful experience of 
Mexico on education through Telenovela and concurrent with that industrialization of infrastructures, India has begun to product Telenovela and concurrent with the economic development, it started cultural discussions due to the presence of Telenovela in peoples' houses. India and Kenya have been successful samples of employing Telenovela in education and development (Singhal, 1991). However, concerning other consequences of Indian Telenovela, it is necessary to refer to the bankruptcy of T.V. industry of Pakistan. According to the studies made in India, in many rural regions, the model of Indian Telenovela have been implemented by many people in their life. In other words, the influence of cable T.V. has caused a change in family violation against women and the autonomy of women could be felt noticeably. The control and reduction in birth rate and unwanted pregnancy have been made and greater power of women has led to the increase of the number of students (Pulley, 2005; Jensen, 2008). A comparison of the statistical community of rural women who have had access to T.V. and Telenovela shows that the physical violation in the families who have had T.V. has been decreased as compared with others. Also tendency to have male child by the women in the villages with access to T.V. has reduced and the shade of the patriarchal culture has been less felt (Mankekar, 1993).

\subsection{Iran}

Basically Technology has changed the method of life of all people in the world and the new generations are enjoying technology and its facilities in a different way. The influence of Telenovela has reached to a position in which the nomadic people are also familiar with it. In the north of Norway, Sweden and Finland, the Samen nomadic people some years ago postponed their calendar of annual collective migration towards the north which has a vital significance for the continuity of survival of the nomadic groups because they wanted to see that in T.V. series who has killed J-R (Postman, 2012).

General Director for Education of Nomadic People in Iran refers to the change in the style of life of nomadic people and considers it an alert for the survival of these groups with thousands of years of history. According to his observations, the nomadic people provide electricity by electrical engine and carry satellite dish with them and watch the Turkish and Colombian Telenovela works. 40\% of Iranian nomadic people in 2014 have migrated with delay as compared with previous years and serious damage has been imposed on their economy and cattle. Authorities attribute the cause of this delay to the addiction-making series and satellite networks (Sattar, 2012).

The first Iranian formal Telenovela dates back to 2006 which used to make the streets empty. Narges series which was in one way or another considered to be a critical social drama, had attracted a high number of addresses. Showing issues such as AIDS and ideological difference between children and family was a king taboo-breaking in this series. Of course, Narges was being broadcasted when many of the social networks and satellite networks did not exist as vast as they are at present. It is worth noting that in addition to a few Muslim countries such as Bahrain, Iraq, Syria, Azerbaijan, Pakistan and Kurdistan of Iraq, countries such as Nicaragua, Venezuela and Bolivia have been the target of Iranian Telenovela (Salgado, 2010).

The Iranian T.V. makes the filmmaker not to be able to show the space inside the house and privacy and overpass the red lines. These sensitivities are big damages towards the believability of Iranian series.

There are two types of issues in this respect:

Religious restriction: we have seen the sample of this type of restriction earlier in the story of Cinema Paraiso film, i.e., detecting that the scenes of a film are suitable or unsuitable by a person based on his ideological beliefs (Tornatore, 1988).

Political restriction: it is like an umbrella whose shade can spread over each subject, person or artistic current which is identified as being in conflict with the interests of the country (Malakmotiei, 2012).

In a strange case, the Oshin series, a product of Japan which used to fascinate Iranians towards TV in the last decade, after being broadcasted in Iran and alteration of the story by dubbing, was changed into a new series. It is to the extent that after watching the original version, today's internet users sarcastically say that the Iranian Oshin should be exported to Japan (Mohsenianrad, 1990).

After 2009 elections, some Persian speaking satellite network outside the country with unknown budgets went on air. Purchasing Colombian, Korean and Turkish series, they restricted the scene to the views of Iranian T.V. and their programs were received highly. One of the last efforts made by Telenovela industry for survival is the supermarket Telenovela [Series which have been sent to the family networks by the private sector with the support of Ministry of Culture and Islamic guidance, Seven Parts for Seven Nights]. Auditing in family network is treated loosely and some of them, such as historical Telenovela namely "Shahrzad", have been successful such that there is an intention to export it abroad. Of course, some series were not completed due to lack of observing 
the concerned values. Family Network [it means the distribution of DVD of Series in episodic forms in centers of distribution, supermarkets, etc.] (Dehghan, 2016).

\subsection{Telenovela El Capo}

The soul of El Capo can be found among the leftists of the Latin America. Fidel Castro, Hugo Chavez, Eva Morales, all have similarities to El Capo. Basically, whoever rebels against poverty and attack at corruption, all Latin people will cheer hurrah for him even if he himself is full of corruption. Capo teaches the lesson of economy of drugs to the Minister of Defense. The cost of plantation of one kilo cocaine and rice is the same but the cost of one kilo cocaine is USD 1000. "Confirming it", the Minister says, "You should know that USA will not let to legalize the drugs". In response Capo says, "Since it wants to use us as a defensive shield and what annoys me is our dependency on USA" (Vilapina, 2009). The dialogues which are uttered by Capo indicate contempt and anger among the Colombians. Capo is responsible to reconstruct the pride of Colombians by aggressing the American soil.

He invades the American soil, makes the criminal gangs to fight each other. Cause the police to be busy, laughs at the performance of FBI and in the end, he ridicules the law of restitution of criminals with the freedom of his son and wife. All the mentioned incidents are a sign of a strong Colombian myth which is the product of injustice, corruption and capitalism and has a selfish interpretation of justice (Vilaplana, 2012).

The leaders of Cartels opposite to what is inspired by media are lovers of Colombia but in their own method, they have frequently proposed the presidents to pay the foreign debts of Colombia. Many times, housing, gymnasium, hospital and church have been built for the poor but the mechanism of democracy and interference of USA have prevented from agreement of the two groups (Zakariaei, 2003). Thus, when we say that Che Guevara, Chavez and Pedro Pablo are similar, it means they have arisen from the spirit of one nation. They inherit one common pain and have one old dream in mind, welfare, independency and power.

At the end of the second chapter, Capo is sent to prison to spend 30 years of imprisonment with American justice. In the third chapter, the myth is again recalled from his place of life. This time he leads a multinational project. The pact project or legalization of drug and decriminalization of drug consumption up to the phenomenon of smuggling, fighting against it and in total violation, a project which has been fulfilled by Jose Mujica, the leftist and moderate president of Uruguay. The fourth chapter has not gone on air yet but it forecasted that in the fourth chapter, the story moves ahead to put an end to Islamic state, Middle East smuggling and expansion of legalization of drugs in the whole world.

\section{Acknowledgements}

In this part, I feel bound to express my sincere thanks to all professors and researchers who have helped me to develop this research. My special thanks go to Prof. Dr. Valles Calatrava and Prof. Dr. Maria Loreto Canton Rodriguez in the University of Almeria, Spain. Last but not least, I would like to express my sincere gratitude to the authors which I have used their views through my library reviews indirectly, though the main sources have been acknowledged in the reference part.

\section{References}

Abbasi, H. (2015). Alias series critics. Tehran, Iran.

Alberto Chong, E. L. (2009). Television and divorce: Evidence from Brazilian novelas. Washington: Inter-American Development Bank.

Andra, C. S. (2012). The Muhannad effect: Media panic, Melodrama, and the Arab femal Gaze. Anthropological Quarterly, 45-77.

Anne, C. (2015). La censura de telenovelas en Venezuela. Caracas: Weblog Class.

Azorín, L. S. (2013). Las telenovelas y su influencia política. In V Congreso Internacional Latina de Comunicación. Tenerife: Universidad de La Lagun.

Azorín, L. S. (2013). Las telenovelas y su influencia política. Tenerife: Sociedad Latina de Comunicación Social, SLCS.

BAŞAR, N. (2015). Iranians learning Turkish to better enjoy tv series.

Berk Esen, S. G. (2017). Turkey: How the Coup Failed. Journal of Democracy, 59-73. https://doi.org/10.1353/jod.2017.0006

Calatrava, J. R. (1990). La novela criminal. Almería: Instituto de estudios almerienses de la diputacion de Almeria. 
Chamy, C. H. (2014). Cómo Turquía está cambiando el mercado de las teleseries de A. Latina. Retrieved from http://www.bbc.com/mundo/noticias/2014/09/140903_cultura_telenovelas_turcas_conquistan_america_lati na_ch

Chomsky, N. (1988). Manufacturing Consent: The Political Economy of the Mass Media. New York: Pantheon Books.

DANFORTH, N. (2016). Turkey's New Maps Are Reclaiming the Ottoman Empire. Retrieved from http://foreignpolicy.com/2016/10/23/turkeys- religious-nationalists-want-ottoman-borders-iraq-erdogan/

Dehghan, S. K. (2016). Shahrzad, la serie tv che sta cambiando l'Iran. Retrieved from http://www.internazionale.it/notizie/2016/05/04/iran-netflix-shahrzad

Forrero, G. (2015). Novela Negra. Obtenido de YouTube.

Ghavam, A. (1996). Political culture, the link between micro and macro analysis. Foreign Policy, 445-462.

Greengrass, P. (Dirección). (2013). Captain Phillips [Película].

Jensen, R. (2008). The Power of tv: Cable Television and Women's. Chicago: School of Public Affairs, UCLA Watson Institute for International Studies, Brown University and NBER.

Mailonline, S. M. (2014). North Korean officials executed "for watching South Korean TV soap operas" in Kim Jong-un's latest purge. Retrieved from http://www.dailymail.co.uk/news/article-2812475/North-Korean-officials-executed-watching-South-Korean -TV-soap-operas-Kim-Jong-s-latest-purge.html

Malakmotiei, K. (2012). Special conversation with Mr. Kamran Malakmotiei.

Mankekar, P. (1993). National Texts and Gendered Lives: An Ethnography of Televsion Viewers in a North Indian City. Arizona: American Ethnologist.

McDonell, S. (2016). Will new censorship kill Chinese filmmaking? Retrieved from http://www.bbc.com/persian/arts-38315602?ocid=socialflow_facebook

McKnight, S. A. (2007). Religion and Francis Bacon's Scientific Utopianism. Zygon, 463-486. https://doi.org/10.1111/j.1467-9744.2007.00463.x

Mohsenianrad, M. (1990). Oshinism Phenomenon. Media, 82-88.

Natalia Ferreira Barbosa, S. M. (2016). Turcos, tan lejos y tan cerca. Retrieved from http://www.ultimahora.com/turcos-tan-lejos-y-tan-cerca-n981623.html

Nora Mazziotti, J. M. B. (1993). El Espectaculo de La Pasion: Las Telenovelas Latinoamericanas. Buenos Aires: Colihue.

Ohadi, M. (2012). Narratology of Film and Television. Tehran: Faculty of Radio and Television of Republic Islamic of Iran.

Pardo, D. (2015). A quién beneficia la caída de las telenovelas venezolanas? Retrieved from http://www.bbc.com/mundo/noticias/2015/08/150820_venezuela_telenovelas_dp

Philip, N., \& Howard, M. M. (2011). The Upheavals in Egypt and Tunisia: The Role of Digital Media. Journal of Democracy, 35-48.

Postman, N. (2012). Assuming ourselves to death public discourse in the age of show business. Tehran: Etelaat.

Pulley, B. (2005). The Billion Dollar BET: Robert Johnson and the Inside Story of Black Entertainment Television. New Jersey: Wiley.

Salgado, A. (2010). Telenovelas Irani? $\mathrm{http}: / /$ salgadoperiodismo.blogspot.com.es/2010/07/telenovelas-irani.html

Sattar, M. (2012). The Nomads watch Television programmes on satellite.

Shobeyri, D. (2013). La traducción de Shahnameh a español.

Singhal, A. A. (1991). Hum Log story: From concept to after effects. Communication, 17-25.

Tali, D. (2016). An unlikely story: Why do South Americans love Turkish TV? Retrieved from http://www.bbc.com/news/business-37284938

Tornatore, G. (Dirección). (1988). Cinema Paradiso [Película]. 
UNUR, A. K. (2015). Discussing transnational format adaptation in Turkey: A Study on Kuzey Guney. Istanbul: Doğuş University.

Verón, E. (1997). Telenovela: Ficción popular y mutaciones culturales. Barcelona: Gedisa.

Vilapina, L. (Dirección). (2009). El Capo [Película].

Vilaplana, L. (Dirección). (2012). El Capo II [Película].

Vu, H. (2013). Study of soap operas reflects media influence in Southeast Asia. Obtenido de University of Kansas. Retrieved from https://journalism.ku.edu/cherry-picked-study-soapoperas-reflects-media-influence-southeast-asia

Yong, L. S. (2014). SBS Drama “Dr. Stranger” Getting Northern Viewers. Obtenido de Daily NK. Retrieved from http://www.dailynk.com/english/read.php?num=11974\&cataId=nk01500

Zafer Yoruk, P. V. (2013). Soft Power or Illusion of Hegemony: The Case of the Turkish Soap Opera "Colonialism". International Journal of Communication, 2361-2385.

Zakariaei, M. A. (2003). Sociology of business crime. Addiction Studies, 185-195.

Zalewski, P. (2012). Why Is Turkey's Prime Minister at War with a Soap Opera? Retrieved from http://world.time.com/2012/12/26/why-is-turkeys-prime- minister-at-war-with-a-soap-opera/

\section{Copyrights}

Copyright for this article is retained by the author(s), with first publication rights granted to the journal.

This is an open-access article distributed under the terms and conditions of the Creative Commons Attribution license (http://creativecommons.org/licenses/by/4.0/). 